This item was submitted to Loughborough's Research Repository by the author.

Items in Figshare are protected by copyright, with all rights reserved, unless otherwise indicated.

\title{
Getting in with the "In" crowd: how to put marketing back on the CEO's agenda
}

PLEASE CITE THE PUBLISHED VERSION

http://dx.doi.org/10.1108/JOSM-02-2014-0041

PUBLISHER

(C) Emerald Group Publishing Limited

VERSION

AM (Accepted Manuscript)

LICENCE

CC BY-NC-ND 4.0

\section{REPOSITORY RECORD}

Klaus, Philipp, Bo Edvardsson, Timothy L. Keiningham, and Thorsten Gruber. 2019. "Getting in with the "in" Crowd: How to Put Marketing Back on the Ceo's Agenda”. figshare. https://hdl. handle.net/2134/14393. 
This item was submitted to Loughborough's Institutional Repository (https://dspace.lboro.ac.uk/) by the author and is made available under the following Creative Commons Licence conditions.

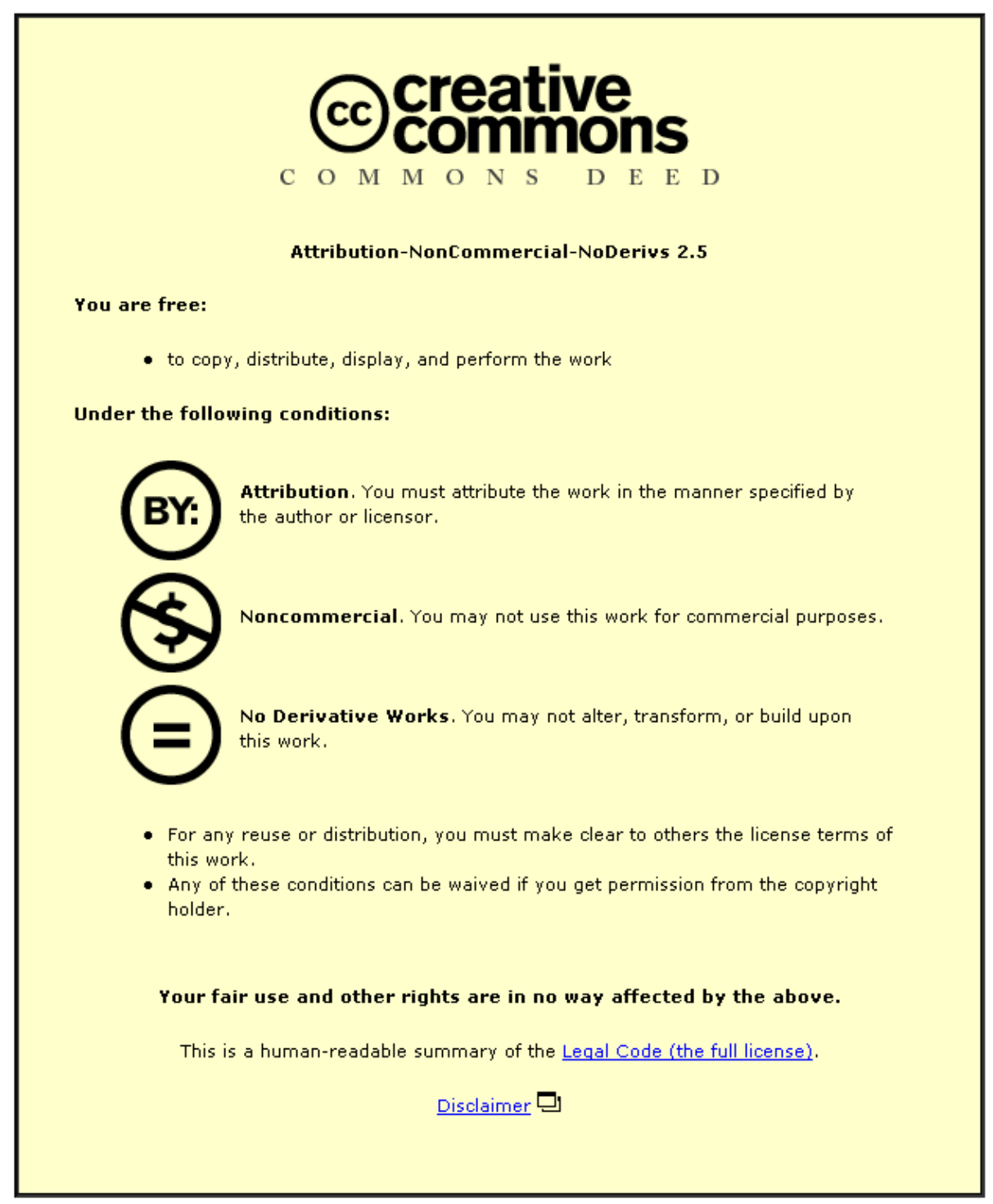

For the full text of this licence, please go to: http://creativecommons.org/licenses/by-nc-nd/2.5/ 


\section{Getting in with the "In" crowd: how to put marketing back on the CEO's agenda}

For decades, marketers have been trying to be more accountable and elevate marketing from a purely functional and tactical level (Grönroos, 2006, 2009; Reibstein et al., 2009) to a strategic level (Kumar 2004; Piercy 1991). Yet marketing remains heavily criticized for its inability to present compelling evidence of the effectiveness of the huge sums it directs to promotion and brand building (Verhoef and Leeflang, 2009). This perceived lack of accountability is linked to a reduction in marketing's influence in strategic decision-making (Verhoef et al., 2009; Webster, 2005) and a cause of resentment from other functions (e.g., Press, 2013).

In addition, marketing-driven strategic initiatives, such as CRM, are often prefaced with assertions that managers express serious concerns about the value of their investments (Homburg et al., 2007; Srinivasan and Moorman, 2005). Operations and IS researchers, comparing CRM with other enterprise-wide IS programs, conclude that CRM alone impacts neither business performance nor share price (Hendricks et $a l ., 2007)$. This discussion is particularly relevant at this time when so many companies are planning strategic investments in IS enabled marketing programs such as social media, customer experience management and new cloud-based services (Klaus, 2013).

In order to explore how marketing can contribute to the firm's strategic decision making and create tangible value, as claimed by scholars discussing the importance of concepts of value-in-use and value co-creation for companies, we first need to explore the current perceptions of marketing and its role in strategy formation from a firm's point-of-view. We interviewed 25 CEO's of service firms to address this need. Based on our findings we conclude that marketing, while seen as an enabling, or supporting function of a firm, is not involved in either building or designing the firm's strategies. We propose in detail how marketing could build not only the foundation, but also become an integral part of design and development of the firm's strategy. 
The aims of our paper are twofold. First, we explore what constitutes the firm's viewpoint of marketing's role inside the firm, in particular its influence on strategy development and execution. Second, based on these findings we develop a roadmap comprising multiple guidelines on how to elevate marketing to an integral strategy development and execution level.

This paper is laid-out in the following way: First, we introduce, summarize and synthesize the existing literature on the role and impact of marketing on the firm's strategy from the firms'-in particular the CEO's - viewpoint. Next, we explore what constitutes the emerging definition of marketing's role within the organization through the means of a qualitative study. Then we report the findings of our study. Finally we discuss the study's findings, their implications for theory and practice, limitations and future research directions.

\section{Theoretical foundation}

The emphasis of our study is to explore how marketing can be again elevated on the firm's strategic agenda. The focus is therefore not on discussing the multitude of scholarly definitions of marketing, ranging from value creation (e.g., Alderson, 1957), to market orientation (e.g., Kohli and Jaworski, 1990) to customer focus (e.g., Grönroos, 2006). Most of them, regrettably, are of very little relevance to members of the boardroom or to CEOs in particular (Fournaise Marketing Group, 2011). As a result, they are unlikely to be discussed by senior executives in terms of developing corporate strategies. Neither do we attempt to enter the recent prevalent scholarly discussion about applicability of new all-explanatory normative paradigms (Wright and Russell, 2012), given that they do not appear to have caught managers' attention (based on the lack of attention that they receive in the business press).

Marketing, once the darling of executives' strategic efforts, courtesy of Porter's value-chain and competitive strategy framework (Wirtz et al., 2014), has in the last 30 years being demoted from a strategic to a tactical, supportive role (Grönroos, et al., 2014; Klaus et al.,, 2014). Scholars posit that this is due to three main reasons: First, marketing's internal and external bad reputation (e.g., Gummesson et al., 2014). Second, its focus on delimited, function related issues that lack a broader scope 
(Webster and Lusch, 2013). Third, the lack of empirical evidence linking marketing activities to an increase in firm performance (e.g., Verhoef et al., 2011).

Strategy is considered a multi-faceted phenomenon and, in relation to marketing, is often described as a customer-focused resource configuration to obtain advantages in a competitive environment (e.g., Hunt, 2000). Hunt and Lambe (2000) define marketing's contributions to business strategy as: (a) market orientation, (b) relationship marketing, and (c) resource-advantage theory. With new marketing fields revolving around value creation emerging, both, marketing's influence, and the voice of the customer are increasing. Paradoxically, at the same time, marketing's influence on strategy is in decline (e.g., Grönroos, 2009). Scholars observing this trend note that marketers are partly responsible for this dilemma due to their preoccupation with tactical rather than strategic issues (e.g., McGovern et al., 2004).

Marketing managers' and scholars' obsession with placing the customer in the center of their universe might have also damaged their strategic position. To be clear, we do not doubt that understanding customers is crucial and should inform the company's strategy (e.g., Quelch, 2008). The problem, however, is that the customer perspective is often not placed in a cost-benefit framework to the company. As a result, in the boardroom, the customer viewpoint can be quickly brushed aside in lieu of cost cutting, shareholder value, or regulatory compliance (Overby, 2011). Moreover, the importance of customer insight to business success varies by industry and context (Quelch, 2008).

To investigate marketing's reputation and influence in the boardroom we need to investigate the role of the $\mathrm{CMO}$ (Chief Marketing Officer). The disconnect between the $\mathrm{CMO}$ and the board of directors is clearly demonstrated by the fact that CMOs seldom make the transition to CEO, in large part because the hurdles to overcome are considerable. First, while CMO tenure has steadily increased over the past five years, their relatively brief tenures at companies rarely provides them with enough time to understand and test themselves outside of their core specialized skills. The CEO role demands broad-based experience, exposure to different functions, and a good understanding of the core operations of the enterprise. 
The most daunting obstacle for CMOs, however, is that they are seldom able to translate the value of what they do into a language that the board understands. For better or worse, the language of business is finance. As a result, CMOs must demonstrate their value through metrics directly associated with sales, earnings, and market share.

Marketers, on the other hand, typically speak a marketingese (blog.15-ideas.com, 2010) language, filled with terms that are not easily translated into dollars. Terms like brand equity, customer equity, persuasion, and influencers may reflect important factors to a business's success, but they have no easy corollary in finance. CEOs often are not technical people (Moss, 2013), and, as noted earlier, are probably not marketers. They want easy to understand explanations devoid of marketing jargon that have direct links to business outcomes.

This is made all the more difficult by the complexity of the marketing function. Marketing is positioned at the intersection of multiple corporate needs such as innovation, customer experience, sales, and operations. Rarely, however, do they own any of the processes associated with them.

The need for broader experience and a strong understanding of what drives a company's P\&L (Profit and Loss) makes a direct transition from CMO to CEO a bridge too far for most individuals wanting to make the leap. In an investigation of what is required to move from CMO to CEO, consulting firm Spencer Stuart finds, "To become a CEO a CMO must always make a double transition, out of their function, and into a new company. The obstacles facing CMOs with ambitions for the top job are considerable and are likely to be too great for those unwilling to step out of their comfort zone and test themselves in unfamiliar roles" (Birkel and Harper, 2009, p. 1).

\section{Method}

In order to discover CEOs' perceptions of marketing and its role in the firm, the study features a three-step method. First, the study explored the perceptual attributes of CEOs towards marketing and marketers through in-depth interviews. Next, we coded 
and purified the data, incorporating a systematic comparison approach and hierarchical coding to ensure that we observed all the data thoroughly and explored all their dimensions (Strauss and Corbin, 1990). Finally, a panel of judges scrutinized the emerging themes using Emerging Consensus Technique (ECT) (Klaus, 2013).

We achieved data saturation (Glaser and Strauss, 1967) after conducting individual in-depth interviews with 25 CEOs from companies with headquarters in 13 different countries, each interview lasting between 40 and 55 minutes. We conducted the interviews at a pre-arranged location either at the respondents' home or work place, depending on the interviewee's stated preference. Three marketing researchers transcribed and independently coded the data. Coding followed the grounded approach described by Ryan and Bernard (2003), which draws heavily from Strauss and Corbin (1990). We started with open coding within the interviews and extended the analysis to axial coding to compare between interviews. We incorporated a systematic constant line-by-line comparison approach and hierarchical coding exploring repetitions, similarities, and differences (Klaus and Nguyen, 2013). This was done to ensure that we have observed all the data thoroughly and explored all dimensions. This coding approach keeps the researcher focused on data rather "than theoretical flights of fancy" (Ryan and Bernard, 2003, p. 91). It posits that categories are the classification of more discrete concepts. According to Strauss and Corbin (1990, p. 61), "this classification is discovered when concepts are compared one against another and appear to pertain to a similar phenomenon. Thus, the concepts are grouped together under a higher order, more abstract concept called a category".

The 25 volunteer participants were recruited through the existing network of the research team, and no incentives for participation were offered. At the time of the interviews all participants had been in their current CEO position for more than three years. As a result, all participants had extensive experience as CEO (serving as CEO for 4.5 years on average) making them qualified as "a judgment sample of persons who can offer ideas and insights into the phenomenon" (Churchill, 1979, p. 67). A more detailed sample profile is included as Appendix.

The initial categorization of all attributes was the outcome of an extended workshop involving the primary researchers. Each member of the research team named and 
defined every attribute of the CEOs' perceptions based on their individual coding results. In a subsequent stage, researchers discussed differences in their attribute categorization and agreed on revised attributes and dimension definitions. Some attributes appeared in more than one interview. The researchers examined transcriptions and individual codes to identify such repetitions and define standardized attribute names, resulting in a coherent coding structure. This analysis generated a pool of four emerging themes.

To maximize the content and face validity of the dimensions generated from the exploratory research, we adopted the Emerging Consensus Technique (ECT) (Klaus, 2013), which draws on the grounded exploratory approach (e.g., Strauss and Corbin, 1990) and the Q-sorting technique (Funder et al., 2000), and is based on utilizing a panel of expert judges. ECT allows the researcher to develop a validated, clear, and concise labeling of attributes, dimensions, and their individual allocation in the conceptual framework of the phenomenon of interest, employing multiple experts and a combination of behavioral (emerging consensus) and mathematical methods, as recommended in the literature (O'Hagan et al., 2006). The expert panel comprised five marketing academics familiar with the subject of marketing practice and the role of marketing in firms' strategy development and execution.

Employment of the ECT follows six steps (Klaus, 2013): (1) attribute labeling and describing; (2) attribute label and description selection; (3) advanced attribute label and description selection; (4) dimensions and sub-dimensions reliability testing; (5) attribute validity testing; and (6) model readability and applicability testing, described in more detail as follows:

First, we presented each of the panel judges (individually) with the quotes corresponding to the attribute originating from the categorization procedure outlined above. The judges received the quotes in sequential order on one card for each attribute and were asked to name and define each attribute based on the information provided, i.e. the original quotes from the coding references.

Next, we showed the judges the original quotes for each attribute, the names and descriptions for the attribute given by them, and the names and descriptions for the 
attribute given by the research team. Each of the judges was then asked which of the two names and which of the two descriptions fitted the data better. Based on their judgment, a name and description for the attribute was noted.

In subsequent sessions, we gave the judges all possible names and descriptions for the individual attribute, together with the original quotes used to label the attributes. We asked the judges to choose the one most applicable to the name and description of the attribute. The research team then compared the findings and selected the names and descriptions emerging from the judges' feedback. In order to qualify, a name or description for an attribute had to be selected by at least four of the five judges.

Using the Q-sort technique (Funder et al., 2000), we printed each attribute in the initial pool on an index card and asked each panel member to create dimensions and sub-dimensions based on similarity. It was up to the members to decide on the number of dimensions they used, and to find appropriate labels and descriptions of the dimensions. The proportion of agreement among the judges was high, demonstrating high reliability. We calculated inter-rater reliability with Spearman correlation coefficient between the judges' assessment resulting in an $r=0.87, p<0.05$. The sorting procedure (Moore and Benbasat, 1999) generated four main themes. Three attributes were dropped because a number of judges identified them as being too ambiguous to fit into the emerging dimensions.

Next, three marketing academics familiar with the research were given the conceptual description of the four main themes and asked to rate them as either "very applicable," "somewhat applicable," or "not applicable." Themes needed to be rated at least as "somewhat applicable" to be retained. This procedure resulted in retaining all four themes.

Finally, three CEOs and two marketing researchers reviewed the readability and applicability of the dimensions, confirming the four main themes.

\section{Findings}


The study identified four main themes: (1) the role of the CMO, (2) lack of accountability, (3) digital and social media, and (4) lack of strategic vision and impact, which we will elaborate on in the following.

The role of the $C M O$

CEOs display a fair amount of self-criticism when prompted about the role of the CMO inside their firms. CEO 15 states that, "in the last years the CMO moves further and further away from the board," admitting that this is partially due "to (the CMO) becoming the jack of all trades, and perhaps the master of none." CEO 8 elaborates that often "we load everything we believe to be 'customer related' upon the CMO. No wonder they struggle." Our interviewees indicate that, based upon the sheer load of tasks the CMO might find it "to be mission impossible to develop strategic visions (CEO 14)."

Our findings indicate that this task overload and focus on tactical issues, partially initiated by the boards' of directors changing emphasis, might lead to a high CMO turnover. While consulting firm Spencer Stuart reports that CMO tenure has steadily increased to an average of 45 months in 2012 from a low of 23.2 months in 2006, average CMO tenure varies widely by industry (McNary, 2013). CMOs in the automotive, communications, healthcare, and restaurant industries averaged 32 or fewer months in their jobs (Rooney, 2013). The high turnover of CMOs in many industries often leads to CEO frustration. As CEO 25 states, "every once in a while you get a real good one, but (because of their skill set) they don't stay around for too long."

One the other hand, CEOs voice that firms are looking for CMOs with one particular skill set, which can vary according to the strategic direction, "we hire them for a specific purpose. It's almost like hiring a consultant these days." Probed if this is an occasional event rather than being the rule, the majority of CEOs expressed that CMOs are exchangeable due to the short-term tactical nature of their job description. For example, CEO 5 states, 'CMOs are often hired as a 'quick fix' to solve a problem." 
Our findings indicate that the particular skill set firms are looking for has also dramatically shifted from what was once "salespeople and brand gurus (CEO 20)" to “capable analysts delivering evidence (CEO 23)." CEO 8 manifests this trend by stating, "today (in our firm) numbers count more than visions."

\section{Lack of accountability}

CEOs believe that marketers appear to be, "simply put, often disconnected from the financial realities of the business (CEO 4)." In particular CEOs highlight that marketers seem to have, "a different interpretation of results and performance (CEO 13)." While other functions, such as finance and information technology, are seen as reliable and trustworthy, marketers have a tendency to, "underestimate the importance of connecting their efforts and expenses to quantifiable results (CEO 7)." This lack of accountability, in particular in terms of what part of their budget allocation is based on ROI goals, leads to a lack of trust, which in turns drives reallocation of budgets and strategic resources. CEO 11 refers to this challenge by asking, "how can I allocate them (marketing) a budget that disappears into a black box, while others (functions) can deliver me a ROI for every dollar I give them?" The lack of delivering a, "clear trail of evidence (of) how and why the budget was allocated in a particular way (CEO 2)," leads to perceptions of marketers making decisions based upon, "gut feelings rather than a solid ROI analysis (CEO 24)."

It is important to note that even if marketers do use the term ROI, CEOs argue that its meaning is often different than their own. For example, CEO 3 states that, "marketing measures ROI in terms of marketing, such as customer satisfaction and brand value" while they would prefer marketers to deliver numbers about the "most relevant relationship, the one between spending and the gross profit generated from these investments."

Digital and social media

CEOs use the example of digital and social media to highlight why marketing is not perceived on a strategic level. They believe that marketing is, "obsessed with new technologies and media (CEO 15)." CEOs believe that these tools cannot substantiate 
their claim to generate quantifiable results in consumer demand and sales. CEO 7 states, "(I) do not consider digital media as a critical tool to enable their (our) strategy." Moreover, CEOs would prefer if marketers appreciate new technologies as a support tool rather than the focus of their efforts. The inability to prove quantifiable increases in consumer demand adds to the main concern of accountability.

\section{Lack of strategic vision and impact}

The CEOs in our study clearly voiced that marketers have lost sight what they believe their job is-generating consumer demand for the firm's offerings in a quantifiable way. CEOs believe that there often is an apparent "disconnect between our overall strategy and what marketing understands to be our customers' needs (CEO 13)." CEOs describe marketing as a "function not on the top of my every-day priority list (CEO 19)". CEOs believe that there are more urgent tasks to master, such as compliance issues, and to "lead the company (CEO 9)" rather than focusing on marketing. Instead, marketing is viewed as "in essence a cost factor first." By comparison, operations "can use established methods and systems to cut costs (CEO 23)."

It appears that the demise of marketing from the strategic level coincides with the rise of the CMO. Respondents observed, "Once we had a CMO we thought, well, finally marketing is now being taken care of (with) one person overseeing all marketingrelated functions (CEO 4)." CEOs, however, believe that this promise has never been fulfilled. "We thought this (problem with lack of accountability and manageability) would get better, but it got worse (CEO21)." CMOs just seem to have "too much on their plates (CEO21)." And, by "getting caught up in so many projects, they appear to forget what their job/impact is/should be (CEO 9)."

Despite marketers' attempts to develop metrics designed to show their impact on firm performance, these measures often fail to resonate with CEOs. "Brand value! What in God's name is this anyway? It's not as if our shareholders care (CEO 17)." CEO 3 expresses the thoughts of many of his colleagues, "Marketing, great ideas, but no clue how to measure its impact on what really counts." 
We posit that, based on our findings, CEOs do not believe that marketers can be an integral part of strategy development for three main reasons: (1) the lack of financial accountability, (2) marketers' fascination with and focus on new technologies, tools, and frameworks without establishing that they generate consumer demand for the firm's offerings in a quantifiable way, and (3) the resulting lack of trust towards marketers capabilities and towards marketing in general.

\section{Discussion}

Quo Vadis, marketing? Or to be more precise, how can marketing (and CMOs in particular) become indispensable to the firm's strategic direction? Should they play a larger role rather than simply trying to increase the influence of traditional marketing? Does progress hide in integrating the goals of marketing into a larger, more encompassing vision of markets and consumers (Webster and Lusch, 2013), or are we simply over-theorizing what CEOs are looking for in order for marketing to have an impact on strategy?

Our findings highlight the four main themes responsible for marketing's and marketers' lack of strategy development and execution. We believe that these themes cannot be viewed in isolation. They reflect the heterogeneous nature of the current status of, or lack of, marketing in the firm's strategy planning and execution.

We could make the point that CEOs and/or the firms' boards are as responsible for the fall of the CMO and marketing from the strategic agenda as marketers themselves. This discussion, however, will not add any value. CMOs work for the CEOs of their respective organizations, not the other way around. Instead, our contribution lies in acknowledging of and learning from these developments in order to put marketing back on the CEO's strategic agenda.

Reflecting on our analysis one might argue that it features multiple contradictory propositions and arguments from CEOs about why marketing is seen as non-strategic. On the one hand, CMOs are viewed as lacking financial accountability, and obsessed 
with technology rather than delivering revenues. On the other hand, CEOs confuse sales indicators with demand-related indicators.

CMOs could argue that the demands CEOs have assigned to them reflect a tactical rather than strategic focus. Moreover, if CMOs and marketing are pushed towards a tactical rather than strategic emphasis, it will, by definition become more abstract due to marketing's broad and holistic nature. This puts marketing in a 'chicken or egg' situation - to be considered strategic by the CEO, must marketing be tactically focused?

If marketing is disconnected from the firm's strategy, then the firm's strategy would be expected to become less adapted to market needs. Taken to its logical conclusion, this should result in eroding profits and vulnerability to competition. Therefore, there is an overriding need for marketing to become a key component of the firm's strategy. When we refer to "marketing" we mean what company management recognizes as such, and not what scholars and businesses put forward as part of marketing. In fact, we believe that it is crucial to recognize this threat. According to our findings many things that marketing academics think of as marketing that are related to strategy have been co-opted into other functions within the organization. As a result, marketing is ceding ground to other functions rather than expanding its role. If it is not under marketing, the CEO and board will never it consider it to be marketing. Moreover, the business units that take over these marketing tasks consider them to be part of "their" function (e.g., operations, information systems, etc.) and not part of marketing. Therefore, for marketing to succeed in these efforts, CMOs must garner support from all stakeholders: in particular the CEO and the firm's board.

\section{The road back}

To achieve this objective, we propose that marketers augment the traditional sales indicators presented to senior management (e.g., conversions, revenue, etc.) with customer demand-related indicators. Moreover, CMOs must not assume that the CEO or board of directors will know the meaning or relevance of these metrics. Instead, marketers must provide senior management with clear definitions, and tangible links between these indicators and future sales. 
We recommend marketers take ownership of a variety of activities within and outside of what is considered their core functional area, such as marketing related IT and IS initiatives. This would allow CMOs to demonstrate, for example, the possible impact of new media as a supportive tool (with an emphasis on "supportive") in crafting winning strategies (and by winning we mean generating quantifiable customer demand).

Marketing needs to raise awareness that due to a shift of customer expectations and technology-enabled customer communications the face of marketing activities and strategies has changed dramatically. Today's marketers need to develop, manage and monitor the impact of holistic customer experiences. This, by definition, broader emphasis of marketing leads to a function that delegates the implementation and execution of all interactions with consumers, including market research, product/service development, sales, distribution, advertising, and customer service. As a result, marketing must partner with other functions, such as operations and information technology, to ensure success (Saw, 2009).

Thus, the job description of a CMO becomes closer to that of a CEO. In a literal sense, CMOs must see themselves as the Marketing CEO. This means running marketing activities in a manner that parallels that of the CEO in the running the firm. This requires that CMOs shift their perspective to that of a holistic business leader from simply being a manager of the marketing function. As such, it requires a CEO's mindset of seeking to maximize value in a tangible way that can garner the support of the board of directors and shareholders. Ideal candidates need strong analytical and strategic skills, multi-industry experience and cross-functional management expertise (Kerin, 2005), the support of the CEO and "a clear mandate to build marketing competence and strategic thinking throughout the organization" (Webster, 2005, p. 5).

This demands that CMOs demonstrate the strategic value of the marketing function, and its role in generating future revenues, which might not always be immediately be detected by current sales metrics. Marketing needs to overcome its perception of abstraction by developing what scholars refer to as "mid-range" theories and measurements. For example, by delivering evidence for the positive relationships between abstract constructs such as customer experience (e.g., Klaus and Maklan, 
2012, 2013) and word-of-mouth on customers' buying behaviors, CMOs will have a significantly better chance of demonstrating the strategic impact of their actions. The key word here is "demonstrating" the impact and the financial contributions of marketing efforts - managing evidence must be seen as core to the job description of every CMO.

Doing so ensures that firms understand how marketing is meeting the needs of customers in a way that positively impacts business outcomes. To that end we believe that customer experience strategy research can offer important insights into aligning the organization around customer needs and financial results. Moreover, customer experience is considered a case in which the "practice" of marketing is in many ways ahead of "academia." As demonstrated by Klaus et al. (2013), research in the customer experience field cannot only bring a scholarly lens to bear on the new insights of customer experience practice. Rather, it must develop insight capable of linking marketing activities to firm performance (Klaus, 2014). At the same time, it is important that CMOs avoid an "everything is a customer experience problem" as overselling will damage credibility with the CEO.

The focus of our study is to outline how marketing will have a place on the board's strategic table. For this to happen, CMOs must recognize the reality of their positions, and act in a way that engenders the trust of the CEO. CEOs and board members demand a solid understanding of the revenue and profit implications of their decisions. Marketing is traditionally weak in this perspective, but it does not have to be- therefore it must not be! Additionally, the expectations of a CMO are often so broad that success on all fronts is virtually impossible to achieve. Therefore being perceived as successful requires that CMOs do a good job of setting expectations with their CEOs.

First and foremost the focus should be on what is doable that will have a financially measureable impact on the success of the business. Clearly, many vital marketing initiatives will not show immediate business impact. But winning credibility with the CEO (and ultimately with the board of directors) requires measureable, unambiguous successes that can be directly attributed to marketing. 
It is not difficult to see how this often is not done. For example, it is amazing how much of many companies' marketing budgets are spent on end of fiscal year initiatives simply because of "use it or lose it rules" (e.g., Schwartzel 2010; Sheth and Sisodia 2001; 2005). Not surprisingly, many (most?) of these "spend the budget" projects that the authors' have witnessed are ill conceived and have little connection to business results.

CMOs must be good financial guardians of the company's resources. This requires that CMOs act as if they are running a P\&L, and not simply managing a cost budget. This will require setting priorities designed to demonstrate an overall positive ROI. This does not mean, however, that CMOs should focus exclusively on short-term, tactical marketing initiatives that can demonstrate immediate returns. Rather, by focusing on a positive overall return (as is expected of a P\&L), CMOs will be forced to balance aspirational initiatives with more financially concrete projects.

\section{Difficulties facing the CMO}

The greatest difficulties facing CMOs in this balancing act result from three demands of the job: 1) bring the voice of the customer to company, 2) be the guardian of the brand, and 3) drive innovation.

Being the voice of the customer is at the core of the marketing function. In reality much of what is measured and managed in this regard shows little connection to the behaviors customers demonstrate towards the brand in terms of their share of spending (Hofmeyr et al., 2008). Worse still, in many cases actively working to improve these measures is not compatible with market share growth, or even good business (Keiningham et al., 2014). As a result, CMOs must clearly establish the relationship between the customer metrics tracked by the firm and their relationship to performance metrics such as share of category spending, total spending, and market share. While this sounds obvious, all too often it does not happen. For example, recent research by Aksoy (2013) finds that the overwhelming number of CMOs have processes in place to measure and manage customer loyalty. Unfortunately, few CMOs can effectively define what they mean by loyal. To paraphrase Aksoy (2013), how can CMOs manage what they cannot define? 
CMOs also must never allow the pursuit of better customer scores to become an excuse for bad management decisions. For example, the board of directors at a large credit union had charged the CEO with hitting a particular satisfaction level in the hope that this would result in greater market share. The CMO, however, was forced to explain why this was not the correct decision if the desired goal was improved market share. Why? The credit union already had very high satisfaction levels vis-à-vis its competitors. In fact, credit unions have the highest satisfaction level of any industry measured by the American Customer Satisfaction Index (ACSI, 2011).

Unfortunately, the correlation between customer satisfaction and market share in the retail banking \& credit union industry is negative (Keiningham et al., 2014). Moreover, the relationship between satisfaction and share of deposits is very weak (Aksoy, 2014). Therefore improving the satisfaction score would likely have no positive impact on the business. Instead, the credit union needed to minimize the reasons that their customers felt the need to use competitors.

It would have been very easy to simply champion the go for the score objective. Nevertheless, making the hard calls is the job of a CMO. Moreover, demonstrating that marketing makes sound business decisions is exactly what gains credibility with the CEO.

The CMO's role as guardian of the brand is equally perilous. Much of the benefits of messaging and other brand building efforts are difficult to quantify in financial terms. As a result, it is typically viewed by CEOs as a cost (even if they view it as a necessary cost). That is why CEOs tend to cut advertising spending in down times (e.g., Edgecliffe-Johnson, 2012).

Additionally, there is frequently pressure to change the brand, or to over-extend the brand in the pursuit of immediate results. CMOs therefore must sell the importance of a clear brand promise. This is most easily done while demonstrating near-term results from marketing efforts.

Finally, CEOs expect CMOs to develop innovative ideas to spur growth. Often this expected innovation involves moving the brand into adjacent markets or product 
extensions. As noted earlier, the key here is to do so without diluting what the brand represents to consumers.

The great news is that the advancement of social media and other Internet-based delivery systems are opening up new opportunities for breakthrough innovation. Here, however, CMOs need to balance the need to be active in this space with the need for positive financial results. CMOs must avoid the rush to adopt new channels without a clear understanding of the role these new channels play in their companies' overall marketing strategies.

The road back for CMOs (and marketing in general) to its place at the strategy table will not come by marketers simply doing their current jobs better. It requires a change in perspective. If we want CEOs to believe that marketing is in the strategic long-term interest of any firm's success, then we must tangibly demonstrate this to be true.

The first step in this process is to think like CEOs. CEOs deal with complexity as a standard responsibility of their jobs. Therefore, CMOs are unlikely to gain respect by pointing to the increased ambiguity and breadth of their responsibilities. Instead, CMOs need to ask the most basic question- "What would the CEO do?" (CMO.com, 2013). The answer will not always be the best decision for marketing, but by asking this question CMOs will be forced to think through (a) what the CEO expects, and (b) why deviation is in the strategic interest of the company. This allows the CMO to communicate positions in language the CEO understands.

Often this perspective will require that CMOs use the language of finance. This means communicating the financial value of marketing efforts, and balancing aspirational initiatives with proven financially tangible projects. This requires that CMOs develop investment criteria to develop and manage the marketing assets under their control to ensure a positive marketing ROI. One way to achieve is by using midrange metrics, such as real-time tracking, linked to revenue generation, to demonstrate accountability. For example, CMOs can introduce segment level reporting that includes P\&Ls by brand, market, product, distribution channels and end customers. Additionally, Marketing Resource Management (MRM) systems could be used to 
record all key marketing activities (e.g., mailshots, price changes, sales promotions etc.) and the costs of all activities (Shaw, 2009).

Finally, while we have focused largely on marketing's need to improve its focus on tangible, financially accountable efforts, we would be remiss to ignore the fact that great marketing is often a mixture of science and art. Marketing, both as a business function and philosophy (as well as an academic discipline) will always need both sides. Instead of suffering from an inferiority complex because of its artistic aspects, it should be bullish about it. But just as professional artists in other disciplines must balance their creativity and desire to make great art with their need to support themselves financially, so too must marketing.

Insert Figure 1 about here

\section{Limitations and future research direction}

As with all scientific research there are limitations that need to be stated. Our research sought to uncover issues impacting marketing's perceived role within organizations, with a specific emphasis on the lack of strategic influence CMOs have with their CEOs and boards of directors. This information was gathered through indepth interviews with twenty-five CEOs with headquarters in thirteen countries (from North America, Western Europe, and Australia). While this sample represents a judgment sample (Churchill, 1979, p. 67), the relative magnitude of the different issues uncovered cannot be assessed for the population of firms. Therefore, quantitative research needs to be conducted with a large sample of CEOs from around the world to assess the degree to which the issues uncovered reflect companies overall.

Additionally, our investigation was limited to developed, Western markets. Therefore, research into emerging markets and into Asian markets may provide additional issues not uncovered in this research. 
Nonetheless, we believe that these results present compelling evidence of the need for CMOs to better address the needs of their CEOs and boards of directors to ensure a place at the table in strategic decision-making. Furthermore, these results indicate that CMOs must do a far better job of demonstrating the value that only marketing can bring to the long-term success of any organization. 


\section{References}

ACSI (2011), "Credit unions set all-time record for customer satisfaction", The ACSI: Press Release, December 13, 2011, available at: http://www.theacsi.org/acsiresults/press-release-december-2011 (accessed 2 May 2013).

Aksoy, L. (2013), "How do you measure what you can't define? The current state of loyalty measurement and management," Journal of Service Management, Vol 24 No. 4, pp. 356-381.

Aksoy, L. (2014), "Linking satisfaction to share of deposits: an application of the wallet allocation rule," International Journal of Bank Marketing, Vol. 32 No. 1,pp. $28-42$.

Alderson, W. (1957), Marketing Behavior and Executive Education, Irwin, Homewood, IL.

Birkel, F., and J. Harper (2009), "From CMO to CEO: the route to the top," Spencer Stuart, available at:

http://content.spencerstuart.com/sswebsite/pdf/lib/CMOtoCEO.pdf (accessed 1 May 2013).

blog.15-ideas.com (2010), "The danger of speaking marketingese," 15 Ideas, (January 27), available at: http://blog.15-ideas.com/2010/01/danger-ofspeakingmarketingese.html (accessed 13 June 2013).

Churchill, G. (1979), “A paradigm for developing better measures of marketing constructs", Journal of Marketing Research, Vol. 16 No. 1, pp. 64-73.

CMO.com (2012), "Slide show: 5 steps to 'marketing CEO' success", (April 4), available at http://www.cmo.com/content/cmo-com/home/slide-shows/slide-show-5steps-to-marketing-ceo-success (accessed 1 June 2013).

Edgecliffe-Johnson, A. (2012), "Eurozone crisis hits advertising spending", Financial Times, 30 September., available at: http://www.ft.com/cms/s/0/e24477c8-0ae6-11e28de3-00144feabdc0.html\#axzz2SAa8Q5Pz (accessed 2 May 2013).

Fournaise Marketing Group (2011), "FournaiseTrack - Media releases $73 \%$ of CEOs think marketers lack business credibility: they can't prove they generate business growth", available at http://www.fournaisegroup.com/Marketers-LackCredibility.asp (accessed 1 May 2013).

Funder, D., Furr, R. and Colvin, C. (2000), "The riverside behavioral Q-sort: a tool for the description of social behavior", Journal of Personality, Vol. 68 No. 3, pp. 45189.

Glaser, B. and Strauss, A. (1967), The Discovery of Grounded Theory: Strategies for Qualitative Research, Aldine Publishing Company, Chicago. 
Grönroos, C. (2009), "Marketing as promise management: regaining customer management for marketing”, Journal of Business \& Industrial Marketing, Vol. 24 No. 5 , pp. $351-359$

Grönroos, C. (2006), "On defining marketing: finding a new roadmap for marketing", Marketing Theory, Vol. 6 No. 4, pp. 395-417.

Grönroos, C., Holmlund, M. and Strandvik, T. (2014), "The mental footprint of marketing in the boardroom", Journal of Service Management, Vol. 25 No. 2.

Gummesson, E., Kuusela, H. and Närvänen, E. (2014), "Reinventing marketing strategy by recasting supplier/customer roles", Journal of Service Management, Vol. 25 No. 2.

Hendricks, K.B., Singhal, V.R. \& Stratman, J.K., 2007. The Impact of Enterprise Systems on Corporate Performance: A Study of ERP, SCM, and CRM System Implementations. Journal of Operations Management, 25(1), pp.65-82.

Hofmeyr, J., Goodall, V., Bongers, M. and Holtzman, P. (2008), “A new measure of brand attitudinal equity based on the Zipf distribution", International Journal of Market Research, Vol. 50 No. 2, pp. 181-202.

Homburg, C., Grozdanovic, M. and Klarmann, M. (2007), "Responsiveness to customers and competitors: the role of affective and cognitive organizational systems", Journal of Marketing, Vol. 71 No. 3, pp.18-38.

Hunt, S. D. (2000), A General Theory Of Competition: Resources, Competences, Productivity, Economic Growth, Thousand Oaks, Sage Publications.

Hunt, S.D. and Lambe, C.J. (2000) "Marketing's contribution to business strategy: market orientation, relationship marketing and resource-advantage theory", International Journal of Management Reviews, Vol. 2 No. 1, pp.17-43.

Keiningham, T.L., Gupta, S., Aksoy, L. and Buoye, A. (2014), "The high price of satisfaction", MIT Sloan Management Review, forthcoming.

Kerin, R. A. (2005), "Strategic marketing and the CMO", Journal of Marketing, Vol. 69 No. 4, pp. 12-14.

Klaus, P. (2014), "Preservers, transformers, and vanguards: measuring the profitability of customer experience (cx) strategies", DMI Review, Design Management Institute Publications, Vol. 24 No. 4, pp. 24-29.

Klaus, P. (2013), "The case of Amazon.com: towards a conceptual framework of online customer service experience (OCSE) using emerging consensus technique (ECT)", Journal of Services Marketing, Vol. 27 No. 6, pp. 443 - 457.

Klaus, P. (2013), "New insights from practice - exploring online channel management strategies and the use of social media as a market research tool", International Journal of Market Research, Vol. 55 No. 6, pp. 829-50. 
Klaus, P. and Ngyuen, B. (2013), "Exploring the role of the online customer experience in the firms multi-channel strategy - An empirical analysis of the retail banking services sector", Journal of Strategic Marketing, Vol. 21 No. 5, pp. 429-42.

Klaus, P. and Maklan, S. (2013), "Towards a better measure of customer experience", International Journal of Market Research, Vol. 55 No. 2, pp. 227-46.

Klaus, P. and Maklan, S. (2012), "EXQ: a multiple-item scale for assessing service experience", Journal of Service Management, Vol. 23 No. 1, pp. 5-33.

Klaus, P., Edvardsson, B. and Maklan, S. (2014), "Editorial - Back where we belong: marketing as the organization's core strategy", Journal of Service Management, Vol. 25 No. 2.

Klaus, P., Gorgoglione, M., Pannelio, U., Buonamassa, D. and Nguyen, B. (2013), "Are you providing the 'right' experiences? The case of Banca Popolare di Bari", International Journal of Bank Marketing, Vol. 31,No. 7, pp. 506-28.

Kohli, A. K. and Jaworski, B. J. (1990), "Market orientation: the construct, research propositions, and managerial implications", Journal of Marketing. Vol. 54 No. 2, pp.1-18.

Kumar, N. (2004), Marketing as Strategy: The CEO's Agenda for Driving Growth and Innovation, Harvard Business Press, Cambridge, MA..

McNary, T. (2013), "Chief marketing officer tenure now at 45 months", SpencerStuart", available at https://www.spencerstuart.com/who-we-are/mediacenter/chief-marketing-officer-tenure-now-at-45-months (accessed 31 January 2014).

Moore, G. and Benbasat, I. (1999), "Development of an instrument to measure the perceptions of adopting an information technology innovation", Information Systems Research, Vol. 2 No. 3, pp. 192-222.

Moss, M. (2013), “(Salt + Fat 2 / Satisfying Crunch) x Pleasing Mouth Feel = A Food Designed to Addict," New York Times Sunday Magazine, 24 February, p. MM34.

O’Hagan, A., Buck, C.E., Daneshkhah, A., Eiser, J., Garthwaite, P., Jenkinson, D., Oakley, J. and Rakow, T. (2006), Uncertain Judgements: Eliciting Expert Probabilities, Wiley, Chichester.

Overby, S. (2011), "10 great expectations: what CEOs want from their CMOs", available at: http://www.cmo.com/articles/2011/6/14/10-great-expectations-whatceos-want-from-their-cmos.html (accessed 26 April 2013).

Piercy, N. (1991), Market-Led Strategic Change, Thorsons, London.

Press, G. (2013), "Digital marketing battlefield map: CMO vs. CIO and Gartner vs. Forrester", Forbes.com, 10 July, available at: 
http://www.forbes.com/sites/gilpress/2013/07/10/digital-marketing-battlefield-mapcmo-vs-cio-and-gartner-vs-forrester/ (accessed 26 August 2013).

Quelch, J. (2008), "How much time should CEOs devote to customers?", available at: http://hbswk.hbs.edu/item/6037.html (accessed 30 April 2013)

Reibstein, D. J., Day, G. and Wind, J. (2009), "Guest editorial: is marketing academia losing its way?”, Journal of Marketing, Vol. 73 No. 4, pp. 1-3.

Rooney, J. (2013), "CMO tenure reaches 45 months", Forbes (online), 25 April 25, available at: http://www.forbes.com/sites/jenniferrooney/2013/04/25/cmo-tenurenow-averages-45-months/ (accessed 29 April 2013).

Ryan, G. and Bernard, H. (2003), "Techniques to identify themes", Field Methods, Vol. 15 No. 1, pp. 85-109.

Schwartzel, E. (2010), "Businesses spend funds as budget year nears an end", McClatchy - Tribune Business News, 23 December 23, ProQuest. Web, accessed 13 June 2013.

Shaw, R. (2009), "Return on ideas - better results from finance and marketing working together", Joint DMA, CIMA, CIM Report, available at: http://www.cimaglobal.com/Documents/Thought_leadership_docs/cid_execrep_retur n_on_ideas_April\%2009.pdf (accessed 29 April 2013).

Sheth, J., and Sisodia, R. S. (2001), "High performance marketing", Marketing Management, Vol. 10 No. 3 (September-October), pp. 18-23.

Sheth, J. N. and Sisodia, R. S. (2005), "Does marketing need reform?", Journal of Marketing, Vol. 69 No. 4, pp. 10-12.

Srinivasan, R. and Moorman, C., 2005, "Strategic firm commitments and rewards for customer relationship management in online retailing", Journal of Marketing, Vol. 69 No. 4, pp.193-200.

Strauss, A. and Corbin, J. (1990), Basics of Qualitative Research: Grounded Theory Procedures and Techniques, Sage, Newbury Park, CA.

Verhoef, P. and Leeflang, P. (2009), Understanding the marketing department's influence within the firm, Journal of Marketing, Vol. 73 No. 2, pp.14-37.

Verhoef, P. C., Leeflang, P. S H., Reiner, J., Natter, M., Baker, W., Grinstein, A., Gustafsson, A., Morrison, P. and Saunders. J. (2011), "A cross-national investigation into the marketing department's influence within the firm: toward initial empirical generalizations", Journal of International Marketing, Vol. 19 No. 3, pp. 59-86.

Verhoef, P., Lemon, K., Parasuraman, A., Roggeveen, A., Schlesinger, L. and Tsiros, M. (2009), "Customer experience: determinants, dynamics and management strategies", Journal of Retailing, Vol. 85 No. 1, pp. 31-41. 
Webster Jr., F. E. (2005), "Back to the future: integrating marketing as tactics, strategy, and organizational culture", Journal of Marketing, Vol. 69 No. 4, pp. 4-6.

Webster Jr, F. E., and Lusch, R. F. (2013), "Elevating marketing: marketing is dead! Long live marketing!" Journal of the Academy of Marketing Science., Vol. 41 No. 4, pp. 1-11.

Wirtz, J., Tuzovic, S. and Kuppelwieser, V. (2014), "The role of marketing in today's enterprises", Journal of Service Management, Vol. 25 No. 2.

Wright, M. and Russell, D. (2012), "Some philosophical problems for servicedominant logic in marketing", Australasian Marketing Journal, Vol.20 No. 3, pp. 218-223. 
Figure 1. Roadmap to put marketing back on the CEO's agenda

\section{Roadmap to put marketing back on the CEO's agenda}

\section{Current State}

CMO's role

Task overload

Focus on tactical issues

'Outdated' skill set

Lack of Accountability

Disconnected from

firm's 'financial realities'

Lack of trust

Digital and Social Media

Obsessed with 'new

tools and technologies'

Lack of strategic vision and impact

Lost sight of 'core' job

Use of 'irrelevant' metrics

Actions

\section{Future/Desired State}

Focus on managing tasks Reacquisition of core functions Combining brand with 'hard', i.e. data analysis and finance skills

Build a strong financial case for customer-demand-related indicators Use of clear definitions and tangible links to firm's strategic aims

Focus on what supports the firm's strategy and scrutinize new tools accordingly - partner with other functions to demonstrate impact

Become the marketing CEO - a holistic business leader, maximizing value in a tangible way in order to gain support from the board and stakeholders
$\mathrm{CMO}$ being considered as responsible manager for all marketing activities, delivering tangible outcomes

Adopt a CFO mindset and deliver evidence on how marketing activities support and enhance the firm's strategy

Being consider a reliable expert to evaluate new opportunities to support and build the firm's strategy

By demonstrating the shift from a marketing to a more holistic management approach, CMOs will be considered a key strategic component 


\section{Appendix: Sample profile}

ID Sector

CEO 1 Financial Services

CEO 2 Retail

CEO 3 Telecommunication

CEO 4 Financial Services

CEO 5 Financial Services

CEO 6 Financial Services

CEO 7 Management Consultancy United States

CEO 8 Professional Services

CEO 9 Education

CEO 10 Logistics

CEO 11 Retail

CEO 12 Professional Services

CEO 13 Retail

CEO 14 Recreation

CEO 15 Professional Services

CEO 16 Tourism

CEO 17 Telecommunication

CEO 18 Retail

CEO 19 Telecommunication

CEO 20 Retail

CEO 21 Professional Services

CEO 22 Transport

CEO 23 Retail

CEO 24 Professional Services

CEO 25 IT

\section{Firm Headquarters}

England

England

Spain

Germany

Switzerland

Italy

France

Spain

Germany

United States

Luxembourg

Austria

United States

Australia

Canada

Spain

Canada

Italy

France

United States

Italy

United States

United States

Canada 